\title{
Anticancer Effect of Plant-Derived Polysaccharides on Mice
}

\author{
Wenfeng Huang \\ Medical College, China Three Gorges University (CTGU), Yichang, China. \\ Email: xyyxy1999@yahoo.com.cn \\ Received January $10^{\text {th }}, 2013$; revised February $12^{\text {th }}, 2013$; accepted February $19^{\text {th }}, 2013$ \\ Copyright (C) 2013 Wenfeng Huang. This is an open access article distributed under the Creative Commons Attribution License, \\ which permits unrestricted use, distribution, and reproduction in any medium, provided the original work is properly cited.
}

\begin{abstract}
Tupistra chinensis is a widely used medicinal plant in Hubei Province, China. In our study, we investigated the effect of polysaccharides component from Tupistra chinensis on mice in vivo. The mice $\mathrm{H}_{22}$ hepatocarcinoma animal model was established firstly. Then, the mice were fed with different doses of polysaccharides derived from Tupistra chinensis (one time each day). The neoplasm growth condition was analyzed and histological and electron microscopic analyses were performed. Compared to the control, Tupistra chinensis significantly inhibited the neoplasm growth. Large mass necrosis in the mouse model was observed under the light microscope and the necrosis area was significantly increased in the Tupistra chinensis-treated mice. Electron microscopic observations showed that severe apoptosis occurred in the cancer tissue in the mouse model and apoptosis was also significantly increased in Tupistra chinensis-treated mice. Our study demonstrated that Tupistra chinensis could inhibit the growth of $\mathrm{H}_{22}$ hepatocarcinoma. The mechanisms could involve the inhibitory effects of Tupistra chinensis on apoptosis, although the precise mechanisms remained to be elucidated in future study.
\end{abstract}

Keywords: Tupistra chinensis; Folk Medicine; Polysaccharides; Hepatocarcinoma

\section{Introduction}

The genus Tupistra chinensis Baker is very richly distributed in China, mainly in those humid areas such as Sichuan and Hubei Provinces. In folk, its roots or the whole plant could be used as medicine. Traditional Chinese medicine theory holds that the genus Tupistra chinensis is a litter bitter, acrid and cold in nature, also a little toxic [1]. Because Chinese medicine theory also holds its function of clearing away heat, detoxifying, expelling wind, removing dampness, diminishing inflammation, relieving pain and other effects, it is widely used to treat diphtheria, sore throat, stomach pain, bruises, rheumatism, carbuncle swollen sore, snake bites and rabies, etc. Previous studies found that Tupistra chinensis has anti-inflammatory and other pharmacological activities for its ample saponins, polysaccharides and other constituents [2]. The preliminary anti-tumor studies demonstrated that in vitro, the total extract and saponins of Tupistra chinensis can inhibit the growth of some tumor cells, for example, human lung cancer cells. On the contrary, inhibition effect of polysaccharide is not ideal in vitro [3].
However, many experiments showed that many plant polysaccharides have good anti-cancer activity in vivo. For example, Lentinan polysaccharides have been successfully applied to treat cancer patients [4]. The antitumor activity of Tupistra chinensis polysaccharide is unclear in vivo until present. Therefore, the aim of our study is to explore antitumor activity of polysaccharide from Tupistra chinensis in mice.

\section{Materials and Methods}

\subsection{Source of Plant Material and Isolation}

The rhizomes of Tupistra chinensis were obtained from Shennongjia Forest District of Hubei Province and identified by Professor Chen Faju. Polysaccharide was extracted with water, followed by precipitation with different concentrations of ethanol. Before use, polysaccharide powder was dissolved in distilled water.

\subsection{Experimental Animals}

Kunming strain of mice, male and female in half, were purchased from Experimental Animal Center of China Three Gorges University. They were fed ad libitum and 
maintained on $12 \mathrm{~h}$ light/12 h dark cycle, at room temperature. All animals were used according to the related ethical guidelines for animal research.

\subsection{Cell Culture}

$\mathrm{H}_{22}$ mouse liver cancer cells were gifted by the Institute of Molecular Biology, China Three Gorges University. 5-fluorouracil (5-Fu) injection was from Shanghai $\mathrm{Xu}-$ dong Haipu Pharmaceutical Co., Ltd., No. 040903). M199 medium was the products of Hyclone Company. Newborn calf serum was from Gibico Company. $\mathrm{H}_{22}$ cells were cultured and passaged in mouse peritoneal cavity. About 5 - $7 \mathrm{~d}$ the cells were passaged and the third passage of cells may be used for animal model. All the cells were collected, then washed with saline water and centrifuged for three times. And the cell concentration was adjusted to $5.0 \times 10^{7} / \mathrm{mL}$. After Trypan Blue staining to determine the cell activity, only those cells whose survival rate are more than 95\% could be reserved and used.

\subsection{Modeling and Animal Groups}

Anticancer activity in vivo was evaluated against $\mathrm{H}_{22}-$ bearing Kunmin mice, as previously described [5]. Mice were inoculated subcutaneously into the right anterior axillary with $\mathrm{H}_{22}$ cells ( $0.2 \mathrm{~mL}$ each). After inoculation, mice were randomly divided into model group, positive control group, low-dose (50 mg/kg), medium-dose (100 $\mathrm{mg} / \mathrm{kg}$ ) and high-dose (200 $\mathrm{mg} / \mathrm{kg})$ of polysaccharide groups, respectively. Polysaccharide of Tupistra chinensis was given by oral administration daily and the positive control group was given 5 -Fu (20 mg/kg) by intraperitoneal injection for continuous 15 days. At last, the mice were sacrificed and tumors xenografts were stripped and calculated size with drainage method.

\subsection{Histopathology}

Tumor tissue was fixed with $4 \%$ formaldehyde and embedded in paraffin wax. Conventional biopsy and $\mathrm{HE}$ staining were carried out.

\subsection{Electron Microscope Test}

The appropriate size of tumor tissue was fixed with $2.5 \%$ glutaraldehyde for $24 \mathrm{~h}$. Then the following steps were elaborated according to standard procedures including fixing, incubation, rinse, gradient dehydration, embedding and ultrathin section. Changes in the ultrastructure of the cancer tissues of each group were observed under an H-7500 transmission electron microscope (Japan).

\subsection{Statistical Data $(x \pm s)$}

Data were expressed as a mean value \pm SEM and ana- lyzed using SPSS software with $\mathrm{p}<0.05$ considered significant. Data were analyzed using one-way ANOVA to test for significant differences between groups.

\section{Results}

\subsection{General States of Mice}

After inoculated, all the mice were reluctant to move more and eat too much. During the drug therapy, the mice in the model group showed worse state, including fewer eating and drinking, disorderly fur with inferior luster, compared to other groups. No mice died during the experimental process.

\subsection{Effect of Polysaccharide of Tupistra Chinensis on Mouse $\mathbf{H}_{22}$ Liver Tumor Volumes}

Drainage method was used to determine the volume of tumor tissue of mice. Compared to model group, high, middle and low-dose of polysaccharide could significantly reduce tumor volume $\left.{ }^{*} \mathrm{p}<0.05\right)$. But no significant difference existed between polysaccharide groups and positive control group, as shown in Figure 1.

\subsection{Tumor Morphology}

Microscopic examination showed that all cancer tissues were highly atypical. Compared with model group, the large mass of ischemic necrosis in tumor tissue were observed in polysaccharide of high, medium, low-dose group, and the positive group. While necrosis of tumor tissue in the model group is relatively minor. No significant differences were found between polysaccharide groups and the positive control group, as shown in Figure $2(\times 400)$.

\subsection{Electron Microscopic Observation}

The transmission electron microscopic observation showed that polysaccharides of Tupistra chinensis can induce the apoptosis of cancer cells, which deduced from some phenomina, such as nuclear condensation, chromatin margination and apoptotic body formation. Figure 3 showed the typical apoptosis caused by medium-dose of polysaccharide of Tupistra chinensis.

\section{Discussion}

As one of Chinese herbal medicines, Tupistra chinensis has been millennially and widely used in Tujia nationality areas. After taking this drug, many serious illnesses, including those patients with advanced cancer can improve the corresponding symptoms and prolong their survival time. So we speculate that some of chemical constituents present in this plant may exert certain anti- 


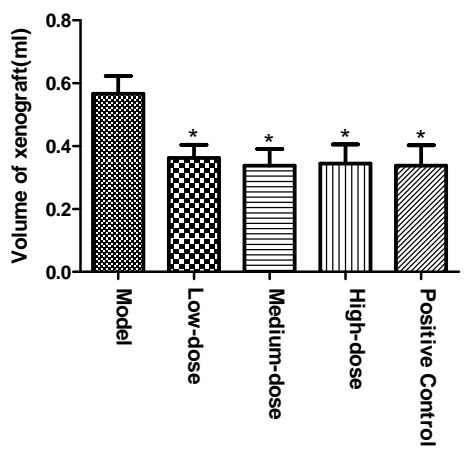

Figure 1. Effect of polysaccharide from Tupistra chinensis on mouse $\mathbf{H}_{22}$ liver tumor volumes. [Compared to model group, high, middle and low-dose polysaccharide could significantly reduced tumor volume $(*<>0.05)$. But no significant difference existed between polysaccharide groups and positive control group.]

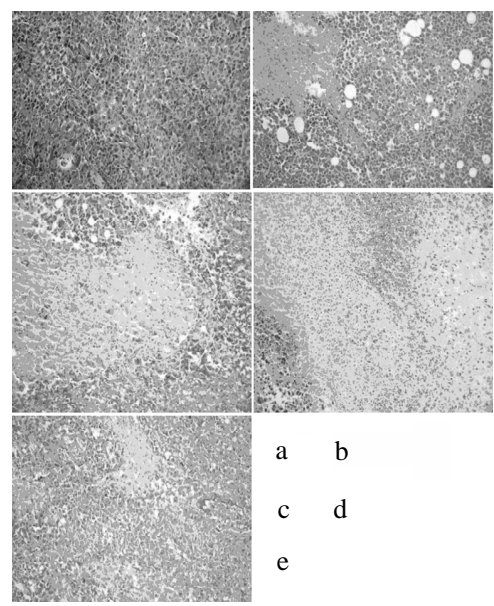

Figure 2. Light microscopic observation of cancer xenograft $(\times 400)$. [The large mass of ischemic necrosis (shown by white arrow) in tumor tissue can be seen in polysaccharide of low (b), medium (c), high -dose group (d) and the positive group (e). While necrosis of tumor tissue in the model group (a) is relatively minor. No significant differences were found between polysaccharide groups and the positive control group.]

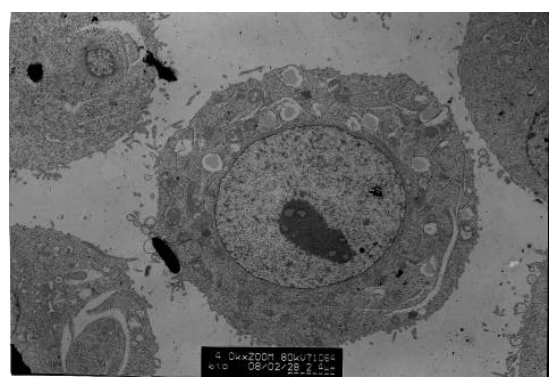

Figure 3. Electron microscopic examination of cancer xenograft. [Many features typical of cell apoptosis, including nuclear condensation, chromatin margination and apoptotic body formation can be seen in the cancer tissue of different dose of polysaccharide. Picture A represented the conditions of medium-dose group.] cancer effect. Our previous reports confirmed that the total extract and saponin components of Tupistra chinensis could inhibit the growth of human lung cancer cells and induce apoptosis in vitro, which demonstrated that Tupistra chinensis can be possible used to cure cancer [3]. Zhu et al. [6] also proved that Tupistra chinensis could inhibit the growth of HepG2 and S180 cells in vitro and in vivo.

Anti-cancer activities of polysaccharides derived from plants have provoked more and more attention, especially, because these kinds of substances are conformed to be low toxic towards human being by a great deal of evidences. When combined with traditional chemotherapy drugs or alone on tumor tissues, it could exert well its function of growth inhibition. For example, polysaccharides from Monostroma and Patrinia scabra were found to have good anti-cancer activity or assist anticancer effects in the clinical $[7,8]$. Also, it was found that content of polysaccharide in Tupistra chinensis was abundant, which drive us to explore whether polysaccharides of Tupistra chinensis exert the same pharmacologic functions as the above plant polysaccharides. So, its anticancer activity in vivo was observed.

This study found that oral administration of polysaccharides from Tupistra chinensis showed no obvious adverse effects on mice. On the contrary, compared with the model, polysaccharide of Tupistra chinensis can significantly reduce the volume of $\mathrm{H}_{22}$ tumor tissue. This pharmacologic effect is the same as the positive control $5-\mathrm{Fu}$, which demonstrated that polysaccharide of Tupistra chinensis exerted better anti-cancer effect in vivo. Further study found that the mechanism of the anti-cancer effect is associated with large mass necrosis of $\mathrm{H}_{22}$ tumor tissue in morphology. While the electron microscopic results also showed that polysaccharide of Tupistra chinensis could induce the typical characteristics of apoptosis in $\mathrm{H}_{22}$ tumor cells, which demonstrated that polysaccharide of Tupistra chinensis exerted its anticancer effect probably through apoptosis pathway.

In this study, since little difference can be found between different doses of polysaccharides of Tupistra chinensis groups, no obvious dose-effect curve can be yielded, which maybe related to metabolism and transform of polysaccharides in the body. Finally, considered that polysaccharides from Tupistra chinensis showed little antitumor activity in vitro, the specific anti-cancer mechanisms in vivo of these polysaccharides needed to be clarified.

\section{Acknowledgements}

This work was financially supported by National Natural Science Foundation of China (No. 30870254 and 30670213) and Yichang Municipal Science and technology research and development project (No. A2012-302-34). And we 
specifically thank Mrs. Wang Yaqin and Mr. Li Jiahua, the Experiment Center, Medical College, CTGU for their technical helps.

\section{REFERENCES}

[1] W. B. Pan, L. M. Wei, L. L. Wei, et al., "Chemical Constituents of Tupistra chinensis Rhizomes," Chemical and Pharmaceutical Bulletin (Tokyo), Vol. 54, No. 7, 2006, pp. 954-958. doi:10.1248/cpb.54.954

[2] K. Zou, J. Z. Wang, M. Du, et al., "A Pair of Diastereoisomeric Steroidal Saponins from Cytotoxic Extracts of Tupistra chinensis Rhizomes," Chemical and Pharmaceutical Bulletin (Tokyo), Vol. 54, No. 10, 2006, pp. 14401442. doi:10.1248/cpb.54.1440

[3] C. Yang, Z. Liu and K. Zou, "Anti-Cancer Research of Saponin from Tupistra chinensis Bak. in Vitro,” Lishizhen Medicine and Materia Medica Research, Vol. 20, No. 10, 2009, pp. 2390-2392.

[4] T. Okamoto, R. Kodoi, Y. Nonaka, et al., "Lentinan from Shiitake Mushroom (Lentinus edodes) Suppresses Expression of Cytochrome P450 1A Subfamily in the Mouse
Liver,” Biofactors, Vol. 21, No. 1-4, 2004, pp. 407-409. doi:10.1002/biof.552210180

[5] B. Zhang, Y. Fang, J. Cao, et al., "Involvement of Immune Response in Anti-Tumor Effects of Staphylococcus aureus Filtrate Preparation," Journal of Cancer Research and Clinical Oncology, Vol. 134, No. 3, 2008, pp. 373379. doi:10.1007/s00432-007-0293-y

[6] Z. Zhu, C. Yu and J. Cai, "Anti-Cancer Research of Tupistra Chinensis Bak. Extract," Journal of Chinese Medicinal Materials, Vol. 29, No. 3, 2006, pp. 277-278.

[7] S. Karnjanapratum and S. You, "Molecular Characteristics of Sulfated Polysaccharides from Monostroma nitidum and Their in Vitro Anticancer and Immunomodulatory Activities," International Journal of Biological Macromolecules, Vol. 48, No. 2, 2011, pp. 311-318. doi:10.1016/j.ijbiomac.2010.12.002

[8] W. Z. Lu, G. X. Geng, Q. W. Li, et al., “Anti-Tumor Activity of Polysaccharides Isolated from Patrinia scabra Bunge on U14 Cervical Carcinoma Bearing Mice," The American Journal of Chinese Medicine, Vol. 37, No. 5, 2009, pp. 933-944. doi:10.1142/S0192415X09007429 